University of Nebraska - Lincoln

DigitalCommons@University of Nebraska - Lincoln

Faculty Publications in Educational

Administration

Educational Administration, Department of

2020

Becoming skillful leaders: American school principals'

transformative learning

Taeyeon Kim

Follow this and additional works at: https://digitalcommons.unl.edu/cehsedadfacpub

Part of the Educational Administration and Supervision Commons

This Article is brought to you for free and open access by the Educational Administration, Department of at DigitalCommons@University of Nebraska - Lincoln. It has been accepted for inclusion in Faculty Publications in Educational Administration by an authorized administrator of DigitalCommons@University of Nebraska - Lincoln. 


\title{
Becoming skillful leaders: American school principals' transformative learning
}

\author{
Taeyeon Kim \\ Michigan State University \\ Corresponding author - Taeyeon Kim, email tkim@unl.edu \\ ORCID Taeyeon Kim https://orcid.org/o0oo-0002-2020-9851
}

\begin{abstract}
In this study, I explore how school principals experience transformative learning in relation to leadership development and how these experiences influence their leadership practices and perceptions. Transformative learning is critical for school leaders because it can lead to meaningful learning that qualitatively changes their leadership practices. Assuming that personally significant incidents are important for transformative learning, I analyzed qualitative data collected from 12 school principals in the United States. Analysis revealed that with these transformative learning experiences, school principals established strong foundations of leadership assumptions and strategies by changing and expanding their views of themselves and others. My findings suggest that education for principal leadership development should provide opportunities to explore multiple dimensions of learning, how relationships and school contexts influence leadership decision making, and how principals perceive themselves as leaders. This study contributes to a more dynamic understanding of how school leaders make actual change in their leadership practices.
\end{abstract}

Keywords: Transformative learning, leadership development, school principal, leadership learning

Published in Educational Management Administration \& Leadership 2020, Vol. 48(2), pp

353-378.

DOI: $10.1177 / 1741143218802596$

Copyright (C) 2018 Taeyeon Kim. Published by SAGE Publications. Used by permission. 


\section{Introduction}

Leadership development requires meaningful learning. School leaders are responsible not only for supporting teachers' and students' development, but also for developing themselves as proactive professionals (Cranston, 2013; Drago-Severson, 2009; Louis et al., 2016). Because of the complexity of their work and the demand for growth, continuous learning is vital for school leaders (Antonacopoulou and Bento, 2003; Bush, 2013). This learning involves the acquisition of leadership skills to enact significant change. Given this, research on leadership learning has noted the importance of learning opportunities that lead to qualitative improvement (Danzig et al., 2007; Drago-Severson, 2009). Thus, this study explores learning that facilitates transformation in school principal leadership practices and perceptions.

Although most research on principal learning has focused on formal education programs for leadership development, findings suggest that changes in leaders' practices and perceptions require engagement in informal and personally significant experiences (e.g. Danzig et al., 2007; Mackay, 2012). For example, Mackay (2012: 392) examined linkages between school leaders' earliest experiences and current practices to suggest that shaping leadership practice occurs through "a complex dynamic of personal, contextual, and socially defined influences." Indepth reflection on the participants in Mackay's (2012) study supports Antonacopoulou and Bento's (2003) argument that learning leadership involves a person exploring his/her inner landscape with conscious and unconscious deliberation on prior experiences.

Analyzing such learning through an adult learning lens can help us understand how meaningful learning can induce changes in principal leadership practices. Research on adult learning has often been used as the theoretical foundation for leadership preparation programs (Crow and Whiteman, 2016). Adult learners are self-directed, internally motivated to learn, and more willing to apply their learning by bringing in accumulated experience (Merriam et al., 2013). Informed by adult learning theories, research has indicated that leadership development should emphasize individual leaders' characteristics and the contexts in which they are situated (Zepeda, 2015). Researchers have highlighted the importance of reflecting individual needs and goals in leadership development programs by considering principals' development stages 
and inquiry goals (Drago-Severson, 2009; Kegan and Lahey, 2009). In addition, studies have suggested that effective leadership development programs are work related, problem based, and situation driven (Davis et al., 2013; Friend et al., 2011; Mann et al., 2011).

Findings from existing studies indicate that using an adult learning lens to understand principal leadership development provides theoretical insights into the connection between leaders' internal growth and leadership practices. However, leadership learning literature has often focused on formal education settings (e.g. university preparation and in-service professional development programs) at the expense of informal learning settings, although research has suggested that formal programs are only a part of the influence on principal leadership (Leithwood and Levin, 2005). Moreover, multiple perspectives of learning have not been fully examined in spite of the fact that adult learning theories have expanded our conceptions of learning beyond formal settings and rational dimensions of education (e.g. Merriam, 2007; Mezirow, 2012).

To fill these gaps, I conceptualize learning in both informal and formal settings, and explore how school principals' learning results in changes in leadership practices and perceptions. Drawing on transformative learning theory, which has become a dominant theory in adult learning (Cranton and Taylor, 2012), I examine how school principals experience transformative learning and how these experiences affect their leadership practices and perceptions by using qualitative data collected from 12 school principals in an American Midwestern state. According to Mezirow (2012), transformative learning entails qualitative change in learners' ways of thinking, understanding, and interpreting experiences and contexts. Therefore, I argue that school principals' transformative learning is directly connected to actual change in leadership practices at both the individual and organizational levels. The findings of this article will, thus, help us better understand how school principals develop themselves as insightful, skillful leaders and how these learning processes occur. The questions driving this research are as follows:

1. How do school principals experience transformative learning in relation to their leadership development?

2. How does transformative learning influence school principals' leadership practices and perceptions? 


\section{Learning for leadership development}

Although most school principals have teaching experience and specific qualifications for leadership roles, a school principal needs to undertake multifaceted tasks and practice ethical decision making (Bush, 2013; Hargreaves and Fullan, 2012; Smylie et al., 2005). In this sense, continuous learning is critical for school principals' leadership practices. School principals' learning can be explored with two lines of literature: research on learning theories and research on leadership learning.

\section{Theoretical foundations in learning}

Literature in learning has been silent on the cognitive and social processes of how school principals learn and develop leadership, whereas multiple learning theories have been developed to explain learning processes and outcomes (Vandenberghe, 2003). However, theories from the learning sciences, particularly those which focus on adult learning, provide a comprehensive understanding with regard to how learning occurs in leadership development.

The learning sciences, an interdisciplinary study of learning, provide evidence to better understand the cognitive and social processes of learning and what environments promote effective learning (Immordino-Yang, 2015; Sawyer, 2014). By weaving together knowledge from learning theories developed in multiple disciplines, learning scientists have contributed to establishing basic principles for deeper learning, such as the importance of creating effective learning environments, building on a learner's prior knowledge, and reflecting on their knowledge status (see Bransford et al., 2000; Sawyer, 2014). Nathan and Sawyer (2014) argued that learning sciences combine elemental perspectives on learning, that is, focusing on learning at the level of the individual (e.g. cognitivism, constructionism, conceptual change theory), and systemic perspectives on learning, that is, focusing on situated learning influenced by social and cultural contexts (e.g. social learning theory).

Drawing upon accumulated evidence from the learning sciences, adult learning literature has extended theories of learning to create an emphasis on adult learners' needs and motivations, learning 
processes, and learning contexts (Merriam and Bierema, 2014). Based on features of adult learners and learning environments (e.g. Knowles, 1984), self-directed learning (SDL) and transformative learning have been influential pillars within the field of adult education for more than three decades (Merriam and Bierema, 2014; Taylor and Cranton, 2013). These two theories have been influenced by traditional learning theories, such as those of the humanistic psychologists, which focus on development of the person (e.g. Maslow, 1954; Rogers, 1983), and constructivism, which suggests learning is about meaning making (e.g. Piaget, 1972; Vigotsky, 1978).

SDL has been variously examined as "process, predisposition, and product" in adult learning research (Taylor, 2006: 197). Brockett (1985: 211) defined SDL as "a process where the learner assumes primary responsibility for planning, implementing, and evaluating a learning experience.” In relation to Knowles' (1975) claim that adult learners are willing to take initiatives for their own learning, some scholars have identified characteristics of self-directed learners, such as readiness, self-efficacy, and autonomy (e.g. Candy, 1991; Guglielmino and Roberts, 1992; Long, 1994). Other studies have suggested that SDL can be viewed as a desired outcome facilitated by appropriate instructions (e.g. Garrison, 1997). In addition, focusing on the importance of experience in adult learning settings (Kolb, 2015), multiple scholars have developed theoretical foundations of transformative learning. Transformative learning deals with change (shift) in adult learners' thinking about themselves and their world (Merriam and Bierema, 2014), which is useful for explaining what types of experiences lead to a shift in a learner's frame of reference (e.g. Mezirow, 2000) and how individuals' learning can be linked to social change (e.g. Freire, 2000).

In summary, no single theory of learning can explain the comprehensive processes of learning because each theory has its own foci on certain aspects of learning. However, accumulated evidence from theories of learning suggests that learning can be more effective for school principals as adult learners if several strategies are employed: (1) using both active and interactive learning processes; (2) linking concrete and real-life experiences to new knowledge; (3) taking into account learners' diversity of learning styles and backgrounds; (4) giving adult learners autonomy over deciding learning goals and processes; 
and (5) creating environments to facilitate deep learning (Roberts and Pruitt, 2009; Zepeda et al., 2014). These theoretical foundations provide implications for research on learning for leadership development.

\section{Leadership learning}

Literature on professional development and school-based learning has actively provided evidence of the value of learning for educators. However, its major focus has been on teacher learning and it has tended to overlook school principal learning (Smylie et al., 2005). Research on teacher professional development examined multiple elements of a learning system-teachers, facilitators, professional development program, and learning contexts (Borko, 2004). Studies suggest that teacher learning can be fostered by constructing knowledge, engaging in real-world problems, and developing shared practice in teacher communities (Fishman et al., 2014). Research on organizational learning extends this evidence at the school organization level. Influenced by the structural-social approach to learning, the essence of organizational learning is collective exploration, interpretation, distribution, and evaluation of information. This drives change in schools and encourages innovative practices (Brown and Duguid, 1991). For example, Louis and Lee (2016) showed that school cultures that value trust, academic emphasis, and academic support for students, and possess the core features of a professional community (shared responsibility, reflective dialogue, and deprivatized practice) are positively associated with teachers' capacity for organizational learning. Given this context of school-based learning, school principals are often considered facilitators and leaders who create climates and a culture that support teacher learning and school organizational capacity (Fullan, 2009; Leithwood et al., 2004).

On the other hand, research on principal education underscores the principal as a learner, who is responsible for his/her own learning as a leader to support teachers' and students' learning (Danzig et al., 2007; Drago-Severson, 2009; Drago-Severson and Blum-DeStefano, 2014; Zepeda et al., 2014). In this vein, researchers argued that adult learning theories can provide pedagogical foundations for principals' leadership learning (Crow and Whiteman, 2016; Matthews and Crow, 2010; Zepeda et al., 2014). Studies have suggested that leadership 
learning programs need to consider individual demands and motivations, personal and professional backgrounds, school contexts, and prior experiences, all of which have been described as important elements in adult learning (e.g. Danzig et al., 2007; Davis et al., 2013; Donaldson, 2008; Drago-Severson and Blum-DeStefano, 2014). For instance, Donaldson (2008) indicated that effective learning for principals begins with asking a question that is critical for the learner's own inquiry and reflection. He also argued that utilizing adult learning theories in developing learning programs is useful to "help them both understand how to make sense of their own past experience and to structure better their future reflection" (Donaldson, 2008: 115).

To develop effective leadership preparation programs, researchers have proposed multiple methods that support problem-based and situation-driven learning. Reflective inquiry (Drago- Severson, 2009; Drago-Severson and Blum-DeStefano, 2014), mentoring (Young et al., 2005), and action research (Osterman et al., 2014; Zambo and Isai, 2013) have been described as effective forms of leadership learning because learners exchange feedback on their own problem and become reflective by interacting with others and the surrounding environments. Zepeda et al. (2014) described the characteristics of effective principal professional development as ongoing, job-embedded, active, and collaborative. Effective learning systems support school principals' continuous learning, and this, in turn, is connected to their current and future practices and career development (Peterson, 2002; Zepeda et al., 2014). Although researchers have proposed different methods for programs, they have relied on adult learning theories as pedagogical foundations for principals' meaningful learning.

With regard to what counts as meaningful leadership learning, researchers have agreed that the results of learning should be related to changes in leaders' practices and perceptions. Research findings highlighted transformative learning grounded in adult learning traditions as being useful for explaining a fundamental change in leadership perspectives as a desired learning outcome. Ginsberg et al. (2014: 188) argued that practice-focused leadership programs can shape leaders' transformative learning experiences at work by providing particular learning opportunities that make learners go beyond their "comfort zone" and incorporate their experiences. Their findings suggested that when learners "who are already effective educators" 
repeatedly encounter challenges that discomfort their habituated ways of thinking about their own practices, they start constructing new knowledge of leadership (Ginsberg et al., 2014: 190). Drago-Severson (2009) asserted that authentic learning develops learners' cognitive, emotional, and relational capacities, leading to actual change in their performance.

As such, the majority of the research on leadership learning has been interested in formally arranged education settings for school leaders. Notably, the findings suggest that changes in the leaders' practices and perceptions are reached through engagement in personal and informal experiences inspired by the formal learning settings. Mackay (2012: 392) argued that shaping leadership practice occurs through "a complex dynamic of personal, contextual, and socially defined influences," which is more than observing practices at work and replicating model behaviors. However, literature on leadership learning has focused heavily on formal preparation settings and, moreover, has overlooked multiple perspectives of learning. Thus, this study extends research on leadership learning by exploring principals' learning that results in changes in their practices through formal and informal settings of learning. As the literature has suggested, adult learning perspectives provide a better understanding of how school principals develop their leadership ideas and practices. In particular, transformative learning is important for examining principals' leadership development because it can be linked to their leadership practices. In the following section, I discuss transformative learning theory grounded in the adult learning tradition as a framework of the study.

\section{Transformative learning theory}

Transformative learning theory offers explanations with regard to how school principals' experiences can be linked to meaningful leadership development that yields actual changes in practices and perceptions. Many scholars have accumulated theoretical foundations for transformative learning with regard to cognitive, beyond rational, and social change perspectives (Merriam and Bierema, 2014). According to Mezirow (2012: 76), transformative learning refers to "the process by which we transform our taken-for-granted frames of reference to 
make them more inclusive, discriminating, open, emotionally capable of change, and reflective." Thus, self-regulated and critically thinking adult learners can generate beliefs for guiding actions through transformative learning.

Mezirow (2000: 22) proposed that transformative learning begins with a "disorienting dilemma," derived from an experience or event that does not match a person's preexisting meaning structure. For transformation to occur in such situations, learners must explore new ways of thinking for dealing with the dilemma so they can set a plan, act, and learn from their experiences (Wang and Cranton, 2013). In this process, critical reflection and the context of the learning experiences are important elements. Leaders critically reflect on assumptions such as "why we perceive, think, feel, or act as we do" (Mezirow, 1991: 108). By critically reflecting on fundamental assumptions about themselves and others, their experiences, social issues, and dominant paradigms, adult learners can reinterpret planned outcomes and recreate meaning in the process of transformative learning (Mezirow, 2009, 2012; Wang and Cranton, 2013). Moreover, learners' personal and sociocultural contexts matter in transformative learning (Greenhill et al., 2018; Mezirow, 2012). For example, the learner's background, such as language, cultural interests, and social relationships, may influence methods of communicating and generating knowledge (Mezirow, 2012). Thus, transformation takes place when learners change their behaviors as well as their ways of knowing (Dix, 2016; Greenhill et al., 2018).

In addition to the cognitive perspective, transformative learning can involve affective and intuitive dimensions because learners' subjective feelings and interpretations about their experiences are influential in the learning process (e.g. Dirkx, 2008, 2012; Walker, 2017). Researchers have argued that empathy helps learners identify other perspectives, promote critical reflection, and increase shared understandings (Dirkx, 2012; Stevens-Long et al., 2012). Dirkx (2012) suggested that transformative learning can involve inner unconscious dimensions that relate learners' emotions and relationships to the experience or context. Moreover, Charaniya (2012) showed that transformative learning can begin when learners' cultural and spiritual identities are challenged by disorienting dilemmas. Acquisition of a more critical understanding of self comes when a person's identity is 
expanded through reflective, intellectual, and relational processes in relation to his/her experiences.

In sum, the literature points to three features of transformative learning. First, learning environments are critical for stimulating transformative learning. When learners face events that provoke disorienting dilemmas, transformative learning can begin. As the first step of transformative learning, learning environments should help a person recognize discrepancies between prior experiences and present ongoing thoughts. Second, critical reflection is important for transformative learning. According to Mezirow (2012), without questioning "why are we doing this," transformation does not happen. By critically reflecting on assumptions about themselves and others, their experiences, and dominant paradigms, adult learners can reinterpret the objective and recreate meaning in the process of transformative learning. Third, transformative learning can be understood as a holistic way of learning. Dirkx (2001: 64) asserted that "personally significant and meaningful learning is fundamentally grounded in and is derived from the adult's emotional, imaginative connection with the self and with the broader social world." As such, transformative learning embraces learning through diverse dimensions such as cognition, emotion, body, consciousness, and unconsciousness.

\section{Methods}

I drew on interpretive research traditions (Emerson et al., 2011; Erickson and Gutierrez, 2002) to decide how to collect, analyze, and interpret data because my goal was to vividly describe school leaders' transformative learning experiences. Because an interpretive approach values the subjective realities of individuals, it was helpful to gain in-depth knowledge about the participants' experiences, beliefs, values, and behaviors to answer my research questions (Creswell, 2007). I took naturalistic inquiry as a methodological paradigm because it posits the existence of multiple and constructed realities, interactive relations between knowers and known, and opposition to context-free generalizations (Lincoln and Guba, 1985). Thus, I assumed that the naturalistic inquiry paradigm would provide a better understanding about school principals' transformative learning that 
exists in multidimensional realities. I also chose this paradigm because it helps interpret how transformative learning occurs in principals' daily work (context bounded) through the interactive processes of the participants and their experiences.

\section{Participants and context}

The participants in this study were 12 school administrators who were currently or had previously been school principals in K-12 public schools in an American Midwestern state. As the theoretical framework in this study implies that learners' personal and professional experiences as well as cultural backgrounds can be associated with their transformative learning, I recruited the participants from heterogeneous backgrounds (Patton, 2015). The range of participants expands along dimensions of gender, years of working experience as a principal, and school context. Table 1 provides an overview of the 12 participants. Ten participants were school principals in K-12 public schools, and two were district-level administrators (had been principals before). Five participants were male and seven were female. Their ages varied from 33 to 63, and they had between 3 months' and 14 years' experience as a school principal.

To answer the second research question, I felt that I needed to add observation data about the leadership behavior of principals to examine the linkage between their transformative learning experiences and leadership practices so that I could provide in-depth evidence. Observations help analyze meaning making through social interactions in day-to-day life (Blumer, 1969). This is useful for examining how participants' previous transformative learning is related to their current leadership practices in schools. For this reason, I selected Mary and Arlene as focal participants from whom to collect observation data during multiple school visits. I identified them as information-rich participants for my research questions because they shared their enthusiasm for being a "learner" along with dynamic personal and professional stories with me during the preliminary interviews. I purposely recruited Mary because she is president of the universityaffiliated teacher professional development organization for global literacy and her school is well known for having a diverse student population (e.g. refugee, Latino, African American, and upper-middleclass 
Table 1. Overview of the participants.

\begin{tabular}{llllllll} 
Name* $^{*}$ & Position and institution* & Race & Gender & Age & $\begin{array}{l}\text { Principal Graduate } \\
\text { years }\end{array}$ & $\begin{array}{l}\text { Teaching } \\
\text { experience }\end{array}$ \\
\hline Charles & Principal, Green High School (9-12) & White & Male & 45 & 10 & PhD & Yes \\
Brian & Principal, Ruby High School (9-12) & White & Male & 34 & 5 & MA, EdD & Yes \\
Deborah & Principal, Sunny Public School (PK-2) & White & Female & 49 & 1 & MA & Yes \\
Connie & Principal, Blue Middle School (6-8) & Asian & Female & 33 & 1 & EdD & No \\
Ann & Director, Sandy Intermediate School District & White & Female & 56 & 13 & MA, EdD & Yes \\
Theresa & Superintendent, Sky Public Schools (PK-12) & White & Female & 63 & 14 & MA, EdD & Yes \\
Kyle & Principal, Forest Junior High School (7-8) & White & Male & 36 & 9.5 & MA, EdD & Yes \\
Marvin & Principal, Stella Elementary School (PK-5) & Black & Male & 39 & 4 & MA & Yes \\
Britney & Principal, Rocky Elementary School (K-5) & White & Female & 38 & 3 months MA & Yes \\
Derrick & Principal, Cloud High School (9-12) & Latino & Male & 38 & 12 & MA & Yes \\
Arlene & Principal, Emerald Middle School (6-8) & White & Female & 46 & 3 & MA & Yes \\
Mary & Principal, Diamond Montessori Academy (PK-8) & White & Female & 46 & 7 & PhD & Yes \\
\hline
\end{tabular}

* Pseudonyms

families) in an urban setting. Arlene, on the other hand, volunteered to participate to gain research experience. Her district is known for its highly diverse population in a suburban setting but has more uppermiddle-class families compared to Mary's. I assumed their eagerness to learn and diverse school environments would lead Mary and Arlene to more readily experience transformative learning because research suggests that learners' self-motivated reflections and challenges from complex environments can facilitate transformative learning (Charaniya, 2012; Dirkx, 2012; Mezirow, 2012).

\section{Data generation}

My data sources include interviews, memos, fieldnotes, and school artifacts, all of which enhance the validity of my findings (Maxwell, 2012). In order to investigate school principals' experiences of transformative learning, it is necessary to explore their narratives about and interpretations of their own experiences. Thus, data were mainly collected through interviews with 12 participants between September 2016 and October 2017. I conducted a semi-structured interview lasting between 45 and 70 minutes with each participant in their school 
principal's office (9/12) or via video chat (3/12). For triangulation, I collected school artifacts and observation data recorded in fieldnotes to confirm or challenge the findings from interviews. I visited Arlene's and Mary's schools eight times in total. I observed their daily work and school environments to generate additional interview questions and capture leadership practices that appeared to be connected to their transformative learning experiences. My observations of the focal participants through multiple visits helped me to become a "trusted person" (Glesne, 2006: 63). This, in turn, assisted me in collecting rich data during the interviews. After each observation session, my fieldnotes recorded descriptions of participants' actions, their interactions with others, and school settings, along with reflective analytic memos (Glesne, 2006; Lincoln and Guba, 1985).

I used Patton's (2002) interview guide approach to effectively collect data in a condensed period of time, as well as to make my participants feel comfortable with my questions. To understand participants' leadership assumptions, in interviews, I asked about motivations for becoming a principal and the rewards and challenges of the role. I then explained transformative learning using personal examples and employed open-ended questions to ask about the participants' transformative learning experiences. Because transformative learning was framed as learning experiences that shifted or led to fundamental changes in learners' conceptualizations and behaviors, these interview questions specifically focused on how these experiences were triggered and how they changed participants' leadership perceptions and practices. Based on things I heard and observed before the interviews, I added other questions for Mary and Arlene to clarify their interpretations of specific concepts and practices with regard to leadership. All interview questions can be found in Appendix A. I took fieldnotes on participants' body language, expressions, and other conversational nuances to aid preliminary analysis. All interviews were recorded with a digital recorder and transcribed.

\section{Analytic approach}

My analysis relied on an iterative examination of transcripts, fieldnotes, and memos to identify emerging themes (Emerson et al., 2011; Maxwell, 2012) using multiple cycles of coding and analyses (Saldaña, 
2015). I explored preliminary patterns of themes in transformative learning theory (Mezirow, 2012; Stuckey et al., 2013) in conjunction with analytic memos from each interview to answer the research questions. This generated six initial codes: disorienting dilemmas, critical reflection, and changes in self-awareness, practices, perceptions of others, and worldviews.

The first cycle of coding involved closely reading transcripts and fieldnotes to classify participants' responses into the aforementioned six categories. Changes in practices and perceptions were hard to separate, and my data did not strongly support any shifts in worldviews. Therefore, I disregarded the last code (changes in worldviews) and consolidated data coded under changes in practices and changes in perceptions of others into one category. This yielded two new themes: setting key assumptions for leadership practices and developing leadership strategies. Thus, five codes were decided in the first cycle of coding: disorienting dilemmas, critical reflection, self-awareness as a leader, setting key assumptions for leadership practices, and developing leadership strategies.

Using these five codes, the second cycle of coding considered interactions between the varying codes to explain the influence of transformative learning on leadership development. I also focused on whether the new codes captured participants' perceptions and any emerging themes from the data. I found three sub-codes in the data under the developing leadership strategies code: knowing others better, building capacity of community, and listening to others to make better decisions. Based on the identified codes, the data indicate that transformative learning experiences establish strong foundations for participants' leadership practices by changing their views of themselves and others.

For the second research question, I focused on data from Mary and Arlene. I also included data from the other 10 participants to support the patterns identified in the data from Mary and Arlene. The richness of the data collected through multiple visits enhances the validity of findings. Given the nature of interpretative traditions and the theoretical framework of transformative learning, my intention was to examine in detail the linkages between school principals' transformative learning and their leadership practices. Thus, focusing on two participants with rich observations meant that an intensive analysis of each case and detailed descriptions of the individual's identity and 
context could be provided. This avoids subsuming participants into an anonymous part of a larger whole (Robinson, 2014). The observations conducted in my participants' schools allowed me to identify their lived experiences as school principals and better understand the related contexts of their learning experiences (Auerbach and Silverstein, 2003). Therefore, their accounts were a rich source of vignettes, interpretations, and practices that helped develop my understanding of how transformative learning influences leadership practices and perceptions. In addition, adding an analysis of data from 10 other participants provided scope for developing cross-case generalities (Robinson and Smith, 2010; Robinson, 2014).

To enhance trustworthiness and credibility, I used both transcripts and fieldnotes for coding (Creswell and Miller, 2000) while using memos and annotations to develop themes and trends (Patton, 2015). I invited two experts in qualitative methods and educational leadership for peer debriefing (Glesne, 2006; Lincoln and Guba, 1985), and we reached agreement on my coding system (Smagorinsky, 2008) While coding and writing analytic memos, I sought evidence that would challenge my findings and validate them against rival explanations (Creswell and Miller, 2000; Glesne, 2006). Participants had opportunities to comment on my interpretations to add to the credibility of findings (Creswell and Miller, 2000).

\section{How school principals experience transformative learning}

To answer the first research question about the mechanisms of transformative learning, this section presents two themes: disorienting dilemmas and critical reflection. Overall, my findings indicate that participants' transformative learning was triggered by disorienting dilemmas that provoked cognitive and/or emotional discrepancy. Participants then repeatedly deliberated and reflected on these experiences in relation to their leadership development.

\section{Starting with disorienting dilemmas}

Borrowing from Ann's analogy about her transformative learning experience, transformative learning can be described as "a journey back 
to Oz." This allows us to see different scenes after pushing our way through "tornadoes." Ann said:

Transformative learning gets us to the other side. It's almost like that's what gets you to $\mathrm{Oz}$ and then that's what gets you back home. You can be in this tornado and all these things going on but when it all clears and you open the door, it's transformative learning that gets you to the color and the flowers.

Like Ann's "tornadoes," the interview data revealed that disorienting dilemmas triggered transformative learning in participants. When I asked about their transformative learning experiences, participants spoke about unexpected experiences involving cognitive challenges or emotionally strong feelings. They used language such as "a unique experience," "unexpected," and "amazing" to describe the "turning point" at which they were changed as a leader.

All the participants reported that transformative learning began with experiences forcing them to understand something different from or beyond what they had thought before. Four participants (Ann, Britney, Brian, and Derrick) suggested that when their leadership decisions did not work as anticipated, they reflected on why they did not work and what they had overlooked. This led to transformative learning. Charles, a high school principal, talked about his previous experiences working as an assistant principal in an elementary school. He said working with the elementary school teachers changed his thoughts and attitudes about teacher evaluation. As his work experience had been limited to high schools (he was a high school teacher before he became an administrator) and content based knowledge was crucial in teacher effectiveness at the secondary level, working with elementary school teachers helped him realize that "teachers' expertise in methods about how to teach and how to deal with individual students" should be more valued.

Moreover, the interview data from four participants (Arlene, Connie, Kyle, and Mary) suggested that when people face unexpected situations accompanied by "difficulties," they have to find new strategies to get through such situations. For example, in response to the question, "Why did the doctoral program lead you to transformative 
learning," Kyle said, "because it was so difficult.” He struggled with negotiating the program's multiple and difficult demands. Hence, he had to work more efficiently and develop a balance among tasks. It seemed that experiencing such cognitive challenges motivated participants to change their thoughts and behaviors as leaders.

Participants also showed that an emotional challenge can act as a catalyst for transformative learning. In the following transcript, Deborah discussed sudden threats to her school from a man who broke up with one of the staff members, prompting her to be a more proactive leader. She explained that the man continuously called her school to express his anger and she became frightened about what he might do.

Like I said I never thought that I would feel threatened here at school. I mean this is a school. That's what I said to my husband. Honestly, I was so upset. I said, “I don't understand where the world is coming that suddenly I have to be afraid. That I have to be fearful."

She had never imagined a principal's job having to be done in a world that she had to be afraid and to be fearful, but she faced the event and "had to learn and learn the hard way." For Deborah, the threat appeared to be emotionally scary, and in her first year as a principal she was not prepared for actively managing this kind of safety issue. Britney reported a similar experience with a visitor wanting to enter her school with a gun. Mary also told me about her "instinct" for recognizing danger when a student with special needs threatened her. In cases like these, in which school leaders were not fully prepared for the events, they experienced emotional shock. Furthermore, the data showed that disorienting dilemmas can occur in people's personal lives as well as their workplaces. For example, Charles pointed out "having his own kids" made "a huge difference" in his work as a school principal by changing his "whole approach" to working with parents and students. Mary and Deborah also reported that their lived experiences in foreign countries led to changes in their leadership perceptions.

The participants' responses presented above confirm Mezirow's (2009) argument that transformative learning requires disorienting dilemmas originating from gaps between a person's preexisting meaning structure and a new, outside event. Each participant experienced 
cognitive challenges when faced with unexpected or difficult moments in their professional and personal lives and, subsequently, concluded they needed to learn new strategies.

\section{Critical reflection}

Participants further indicated that critical reflection was important for linking disorienting dilemmas to transformative learning. The data suggest that disorienting dilemmas entail cognitive and emotional challenges, and that transformation of thoughts and behaviors occurs via deep reflection. Participants repeatedly reflected on unexpected and unusual experiences by asking why their strategies did or did not work.

When asked what factors from past experiences influenced his learning, Brian answered: "informed reflections" not "just reflections." Before this interview, he had mentioned his mistakes as a leader"managing not leading" for the school's AP (Advanced Placement exams) plan last year-and how the disappointing results taught him to rethink his leadership.

It's not just reflection. It's informed reflection (with his strong accent) with research that comes into that reflection, the key points, to tell me this isn't working, this is why it's not working or this is my hypothesis about why it's not working. Let's see what resources are out there to help me make sure that this works. Sometimes, I'm able to pull that out from my own memory. Sometimes, I need to find a new resource.

For Brian, informed reflection was a tool for inquiry rooted in strong evidence that explains why a previous strategy did not work. By seeking evidence through his own memory and new resources, he deliberated on and theorized hypotheses to resolve disorienting dilemmas. Similarly, the interview data from all 12 participants suggested that intensive and critical reflection followed disorienting dilemmas.

In critical reflection, participants' responses implied that "asking why" is important. For example, Ann noted the need to know "why (purpose) before "how (process) and what (product)" by "investigating, criticizing, and evaluating." Thus, critical reflection may rely on 
cognitive processes. According to Mezirow (2012), without questioning why, transformation does not happen. The examples above indicate this analytic process promotes school leaders' (re)interpretation of past experiences via the creation of new meanings out of disorienting dilemmas. If this is the case, then how do these learning experiences influence their leadership development? The following section addresses this second research question.

\section{Influence of transformative learning on leadership practices and perceptions}

This section explores linkages between school principals' transformative learning experiences and their leadership practices and perceptions. Emergent themes from interviews with school principals revealed that their growth as thoughtful, insightful leaders was influenced by transformative learning experiences. This section presents three themes: revisiting themselves, setting foundations of leadership, and developing leadership strategies. The first theme highlights participants' reflections on and assessments of themselves as leaders following transformative learning. The second theme illustrates how participants' transformative learning experiences had an impact on their development of key assumptions about leadership perceptions and how those perceptions could be strongly affirmed, but could also change. This process directed participants' subsequent leadership practices. The third theme provides an understanding of how school principals developed leadership strategies based on the former two themes.

\section{Revisiting themselves}

Self-awareness is an important outcome of transformative learning (Stuchey et al., 2013). My analysis supports this because all participants reported that they started to "think about themselves" as leaders while talking about their learning experiences. Brian noted, "who I am as a person matters a lot for leadership," illustrating, therefore, how principals can assess their strengths and shortcomings as leaders through critical reflection. 
In discussing how she felt after having difficulties working as a principal with the staff at Sky Elementary School, Ann told me she had never experienced such difficulties before, and her usual approaches to leadership had not worked. Ann then explained why she decided to leave.

I really started to think about myself. How do I enter a job? How do I act in the job? How does my behavior, how does my cognition, emotional presentation, my interpersonal capacities and capabilities, how does that all affect things? I really took that to heart and started to dissect it. The next job I took was not a principal job. I went back to central office mostly because I knew that I needed some time to reflect and to do some good work and I needed to work with principals again so that they could help me to understand not only myself but how they do their work. Through [working with] them, I was able to repair in myself that what I'd call a bad experience and I will tell you ever since then my leadership experiences have been so much better.

This quotation shows that changes in Ann's subsequent career started with "digging into herself." In this process, she reflected on her entire career by objectifying and reinterpreting herself, and then figured out her weaknesses to "repair" herself.

During her interview, Ann frequently mentioned the self-recognition process whenever she thought about situations related to her experience at Sky Elementary School (six times in the 70- minute interview). Similarly, reflecting on themselves was an important part of other principals' transformative learning experiences, which they asserted are about "really getting to know yourself" and are "absolutely critical as a leader." Mary said, "if you don't know who you are, you can't be solid and lead other people either." Thus, revisiting themselves as leaders enabled principals to think about "how I can help myself," "what I need to do," and "where should I be headed," as a leader.

\section{Setting foundations of leadership}

Another influence of transformative learning was that school leaders 
set "fundamental" and "strong" grounds for their leadership practices. During interviews, participants shared their "lessons" from transformative learning experiences with me. These lessons were connected to their ideas of leadership and provided directions for subsequent leadership practices. Most participants, explicitly or implicitly, reported that events that triggered disorienting dilemmas either changed their leadership assumptions, strongly affirmed what they already thought about leadership, or created new key assumptions about their leadership ideas. Data from interviews and observations revealed that these "lessons" established the foundations of their leadership practices.

In Mary's interview, she told me she undertook a two-year Montessori teacher training course after becoming principal at Diamond Montessori Academy. In the following example, she confirmed that one of her leadership foundations is not asking staff to do things she will not do herself and she explicitly stated this as her philosophy.

Mary: Yeah, and I do a lot of things by example. I will never ask my staff to do something that I won't do, the training being one of them. I can't tell my teachers, "Go to school all summer, do all this work," and then I don't do it. That's not ... (nodding her head)

Researcher: That's your foundation?

Mary: Yeah, because I worked in special education for years ... they have all kinds of multiple impairments. We had to change diapers. We had a lot of behaviors from students, a lot of different things than you would find in general school. My philosophy was just saying, "If I am asking you to go do something, I am gonna to do it too." It's our work. It's our team, and we're all the same.

She affirmed her philosophy of leading "by example" is related to her teaching experiences with students who have special needs. This example also demonstrated how she motivates teachers to achieve school goals.

My observations support the fact that this philosophy is embedded in Mary's leadership practices. She used "hands on" approaches to deal with teachers and students. For example, she planned and delivered two-hour training programs for staff professional development 
meetings every Wednesday. During these meetings, she shared with the staff her difficulties in learning and communicating in Arabic when she worked abroad, relevant ideas from her weekly universitybased leadership training program, how she dealt with stress, and her utilization of mindfulness techniques. She also visited teachers and staff in their classrooms and offices to talk about various issues related to students, parents, and school administration, instead of waiting for them to come to her in the principal's office.

Additionally, Mary tries to be a model for her students. For example, she introduced me as a scholar on the sane degree program as herself as a way of encouraging them to keep studying hard in the future. In this case, she used both me and herself as models of enthusiastic learners. These examples show how Mary recognizes the value of modeling continuous learning for both teachers and students. Because promoting learning is central for her, being a model learner sets the foundation for many of her leadership practices.

Similarly, five other participants (Britney, Connie, Deborah, Derrick, and Keith) explicitly said their "transformative learning" altered their leadership assumptions. For example, Kyle reported that his doctoral program experiences changed his perception of leadership from "having the work done" to "making it better." The interview data from three participants (Ann, Arlene, and Charles) showed that transformative learning resulted in a remapping of their leadership priorities. All three told me their focus on relationships moved to the center of their understanding about leadership. Through several unexpected experiences, Arlene established her key assumption of leadership: "relationships are key." In the following fieldnote, I narrate how I perceived relationships to be important to her and why she thinks this.

Arlene mentioned "my philosophy is that relationships are key" in my first visit, and during the interview today, she affirmed this again. She told me about her middle school teaching by saying that "middle school students know that the people around them care about them. Then they will move mountains for you." This relationship point appeared when she was talking about the story of difficulties with parents in her first year [as a principal]. She realized again that "once that relationship breaks down, then that's when you have 
conflict, and that's when you have problems, and that's when you can't be productive."

During the 73-minute interview, she came back to this relationship idea 11 times, and mentioned the term "relationships" 23 times. She self-identifies as "a person who wants to avoid conflicts and controversial conversations." This shows that Arlene seemed to believe having good relationships with staff, students, and parents helps avoid such problems.

\section{Developing leadership strategies}

Finally, my analysis reveals that participants developed their leadership strategies through transformative learning experiences. As participants reflected on themselves and established key foundations for leadership referenced in the earlier themes, they reported assembling new strategies as school leaders based on these perceptions. Although they focused on different areas to develop their strategies, these strategies could all be categorized into three themes: knowing others better, building capacity of community, and listening to others to make better decisions. This section presents how each of these leadership strategies was influenced by the participants' transformative learning experiences.

Knowing others better. I found participants' transformative learning "lessons" helped them develop more open perspectives about others. They were able to understand more about how teachers, students, or parents might feel in a given situation and how those feelings might influence behavior. For example, Mary was particularly committed to making efforts to learn about individual students' stories to build relationships. In the following transcript, Mary discusses how she approaches students from diverse backgrounds, a point that came up via conversations about her international working experiences and difficulties in relation to living in other countries (e.g. Malawi, China, Tunisia).

We have a lot of refugee children, and other children who come from homes where reading is not valued. They have 
very poor literacy skills. They don't know how the system works. They don't like the food. All these adjustments that they have to make to come to school every day that most of us take for granted because we're here. It is a big adjustment for a lot of children that comes from these different homes and situations ... you don't really know it until you experience it and it's personal to you, and then you understand and you get it.

This example highlights how she relates to students facing major adjustments through her personal experiences. In particular, as Mary mentioned, her school has a large proportion of students from poorer families. It seems her own struggles in foreign countries help her better understand her students' environments and what types of support they need. For Mary, "diversity" is not a group difference, but an individualized one. She noted "every student and teacher is different" and, thus, she uses "different strategies for each person," which aligns with her conceptualization of Montessori education. This has enabled her to develop an individualized knowledge of different students and teachers.

The following vignette, observed when Mary and I checked in with each classroom in the late morning, demonstrates how she applies strategies to get to know her students better.

While we were walking to Mr. Hans' classroom, we encountered a teenage boy in the hallway. He was smiling and saying "Hello, Dr. Jones, how are you?" Mary said (while smiling) "Hello Mathew! Good to see you. Are you volunteering for Mr. Han's classroom?” Mary let him introduce himself to me. Mathew said he graduated from this school about two years ago and now he is a senior at high school ... Mary asked him about his two other brothers in great detail and his grade. When he said "It's a B," Mary said "B's not high enough, why not an A?" (touching his shoulder). They were all laughing together. Mary told him "One day, you can be a student at Blue University where she [the researcher] works, remember." While walking to another classroom, Mary told me "We're tracking all students after graduation, 
and make sure that "we (her and her teachers) are watching you [them]". I don't think they get these expectations from home ... this is important."

This fieldnote illustrates her specific strategies for learning about students and teachers. She remembers the names of all the students and their family stories, even for alumni. She also cares about individual teachers and their situations. As Mary noted, it is important for her to "know where you are coming from, what that story is," to support students and teachers as a leader. Additionally, when talking with students she called them by their names ( 21 times during 16 hours of observations). Mary even visits students' homes to encourage them to come to school and focus on learning.

Building capacity of community. The second leadership strategy influenced by participants' transformative learning was building capacity of community through developing teachers and expanding community resources. In reflecting on their transformative learning experiences, the principals as school leaders wanted to help their teachers grow as leaders too. Arlene, Britney, Derrick, Mary, and Theresa reported that they applied new and modified strategies to build up their "team."

Mirroring her special education administration experiences, Arlene identified how such work causes teachers to experience burn out very quickly. Nevertheless, she valued what she learned serving in this capacity and sought to share it with teachers. In the following transcript, she speaks about her "shared leadership" approach in relation to teachers' professional development.

I want my teachers to have learning opportunities that benefit them ... I have to have shared leadership. There's no way that I could do this all on my own. And so, I put a lot of the leadership responsibility either on the curricular chairs, or my instructional leadership team or behavior team. To drive initiatives, to drive the learning of our teachers. So it's not coming from me. It also helps with buy-in. So, if I say "Okay, this is what I'm thinking, what do you think?" teachers will say, "I think it looks great." But it needs to come from the teachers not from me. 
This quotation shows that Arlene's previous learning from special education, which became her "transformative learning" experience, influenced her adoption of shared leadership strategies for teacher development. Her school documents show that teacher professional development and departmental meetings were led by teacher leaders. Parents I encountered in her school described how they felt Arlene "empowers and supports teachers" when they talk to teachers and attend school events. For her and other principals (Britney, Derrick, Mary, and Theresa), having a team is important for collectively achieving their vision and goals for the school. Developing teachers as leaders was influenced by the principals' transformative learning experiences. In support of this finding, Theresa changed her district's teacher professional development programs from top down to bottom up after recognizing the benefits in her own training.

In addition to building teacher capacity, Arlene, Mary, and Richard increased their efforts to develop school community resources. For example, during the seven years of being a principal at Diamond Montessori Academy, Mary built networks with over 30 organizations. Her school is relatively small and does not have enough resources to support a diverse group of students so, instead, she developed her connections with the community to gain support. During my month of fieldwork, her school twice had international visitors from Blue University. On each visit I saw many types of volunteers: parents, high school students, students from Blue University, and retired people who came to help English as a Second Language (ESL) students with reading. All these connections resulted from Mary's efforts to provide better resources for her diverse group of students. Mary articulated, "they don't come just because they want to help [students]. They come because they have a connection with me." Similarly, Arlene pointed out the importance of connections with community members and Blue University programs, both of which provide opportunities for helping students.

Listening to others to make better decisions. Finally, my analysis reveals that participants tried to listen to others' opinions to make better decisions as a result of their transformative learning. As noted in the theoretical framework, learners reinterpret their contexts and experiences throughout the process of transformative learning (Mezirow, 
2012; Taylor and Cranton, 2013). Participants affirmed this in noting that their transformative learning experiences helped them listen attentively to others' advice and more thoroughly assess circumstances to make better decisions. This tendency was more frequently found in data from principals relating to earlier career stages.

For example, Arlene told me about some "horrible" events in her first year as principal at Emerald Middle School that prompted her to change her strategies for making executive decisions. In the following example, she talks about "making a pause" and "getting more feedback" as being her revised strategies.

I think that sometimes when I make decisions that I should just pause and get more information, more feedback. And, I've learned that, though over the past couple of years. I would make decisions without getting more feedback from people. And so, now I kind of pause when I make decisions to say, okay, is this something that I should run by the superintendent . . . Is this a decision that I need teacher feedback on? . . . So, I have learned in the last, so maybe that's part of that transformative learning based on mistakes I have made in making decisions too quickly. That, makes me pause and think about, okay, before I make a decision, who do I need to talk to before?

Arlene thought her previous mistakes were from "making decisions too quickly." Reflecting on this, she became more thoughtful and deliberate about making decisions by assessing situations and seeking feedback.

Similarly, Mary also works closely with parents regarding student suspension. However, unlike Arlene, Mary highlighted her ability to make better, quicker decisions than those she made in her early years. She told me: "In the beginning, I didn't know the parents, and we would have a 20-minute conversation. Whereas now I can have a 2-minute conversation with that same parent. Then do a better job." Mary's strategy, listening to others but making quick decisions, was affirmed in fieldnote observations. Serena, a bus driver, described conversations with Mary regarding student suspension and noted: “I like working with her, I've been working here for three years and 
she's very good at dealing with problems. She works fast, immediately, when something goes wrong, she doesn't wait until it becomes worse."

Although Arlene and Mary both used the common strategies of listening to others in making decisions, the differences between "pause" and "quick" can be explained by their previous transformative learning experiences and length of time working in the same school and district. Mary is in her seventh year with the same school and has been in the district even longer, whereas Arlene is only in her third year in the school and the district. These distinctions reflected significant differences in their relationships with parents and the local communities. Moreover, Mary's transformative learning led her to make decisions immediately to avoid risks, whereas Arlene experienced negative consequences from making decisions quickly without first thinking about possible alternatives. As such, data from all 12 participants highlighted changes in decision making with a shift toward listening to others' voices; however, based on personal experiences and school contexts, the two participants developed different strategies to make better decisions.

\section{Discussion}

The findings of this study reveal that school principals experience transformative learning through disorienting dilemmas and critical reflection (Research Question 1). In relation to principal leadership development, these experiences lead them to reexamine and assess themselves as leaders, establish strong foundations of leadership assumptions, and develop leadership strategies by changing and expanding their views of themselves and others (Research Question 2). Figure 1 gives an overview of the findings, specifically, how and where the mechanisms of influence work.

For participants, transformative learning started with "disorienting dilemmas" triggered by emotionally and cognitively challenging unexpected incidents (Dirkx, 2008; Mezirow, 2000, 2012). Critical reflections, in which participants asked "why" their knowledge and skills did not work, then followed (Mezirow, 2000, 2012). Throughout this cognitive process, participants reflected on and assessed themselves as leaders, set key assumptions (philosophies) for their leadership 


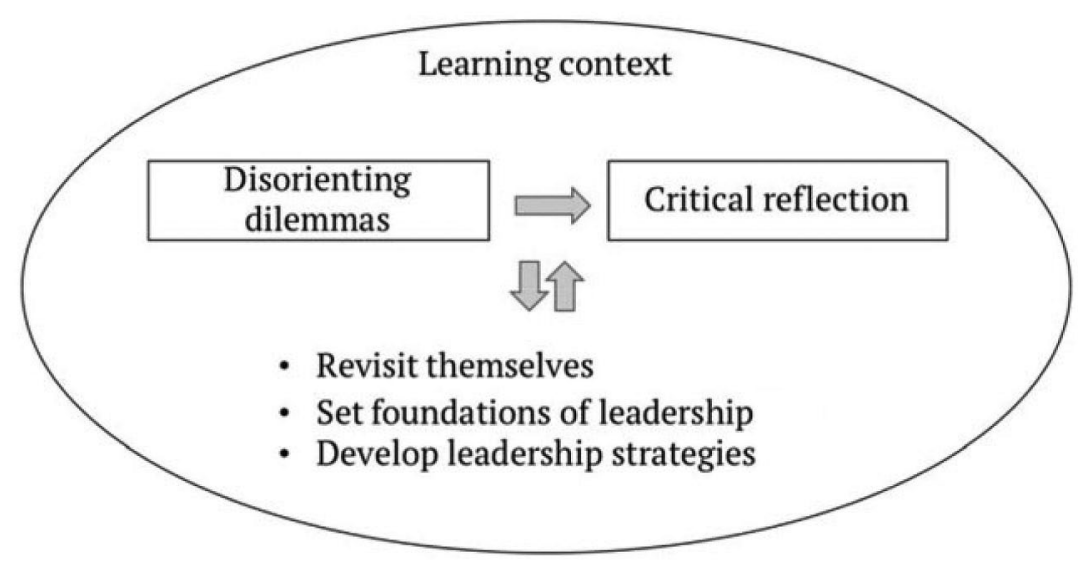

Figure 1. Mechanisms of transformative learning in principal leadership development.

practices, and developed strategies: knowing others better, building capacity of community, and listening to others to make better decisions. Importantly, analysis suggests these cognitive processes interact with contexts of learning. School leaders face complex education environments, and participants developed key principles that guided them to their long-term leadership practices; however, they also continually evaluated these principles and developed new strategies for reflecting on each context.

These findings underline the value of experience-based learning as highlighted by the literature on adult learning and leadership development (Ginsberg et al., 2014; Merriam and Bierema, 2014; Roberts and Pruitt, 2009; Zepeda et al., 2014). Although research on leadership development, grounded in adult learning theories, has focused on adult learners' characteristics and their learning styles (e.g. SDL), most evidence was limited to learners' experiences when undertaking formally organized programs (e.g. Ginsberg et al., 2014; Mackay, 2012). However, this study extends existing literature by identifying what experiences matter for school principals and how their learning mechanisms influence leadership practices beyond formal learning settings. Within these findings, I discuss three points in relation to principal leadership development.

First, my findings suggest that principals' meaningful learning can begin with personally significant experiences that occur in their personal and professional lives through unexpected challenges. 
Participants' transformative learning involved personal experiences (e.g. international travels, family milestones), previous teaching experiences, working experiences as principals, and preparation programs. Although two participants (Kyle and Teresa) mentioned preparation programs, informal learning settings were more frequently mentioned by participants. Other research findings support this result, which highlights engagement in informal and personally significant experiences as important for leadership learning (Danzig et al., 2007; Mackay, 2012). Findings also suggest that not all experiences are linked to learning. Experiences that challenge a principal's preexisting meaning structures and require efforts to build new knowledge are what lead to transformation in a principal's leadership practices ( Merriam and Bierema, 2014; Mezirow, 2000; Wang and Cranton, 2013). As discussed earlier, Ginsberg et al. (2014) argued that school principals, as adult learners, are already experienced and effective educators; therefore, school principals' disorienting dilemmas can play a significant role in guiding them to go beyond their "comfort zone" by challenging habitual practices and ways of thinking (Ginsberg et al., 2014).

Second, the results indicate that principal leadership development should embrace multiple dimensions of learning: cognitive, emotional, and intuitive. Although learning theories have emphasized the importance of non-cognitive, emotional, and physical elements in learning (Dirkx, 2012; Immordino-Yang, 2015; Sawyer, 2014), the literature on leadership education mainly focuses on cognitive dimensions. My findings suggest that transformative learning requires critical reflection on disorienting dilemmas that provoke an emotional, physical, or intuitive reaction. The participants vividly discussed "horrible," "painful," and visceral feelings resulting from disorienting dilemmas that caused transformative learning, even dating back to a decade ago. My analysis showed that this multidimensional learning can be achieved through interactions with others rather than from learning alone. This result is confirmed by learning theories that promote interactive processes (e.g. Brown and Duguid, 1991; Immordino-Yang, 2015; Sawyer, 2014). Literature on school-based learning (e.g. Louis and Kim, 2016) and principal education (e.g. Drago-Severson and Blum-DeStefano, 2014; Osterman et al., 2014) indicates that interactions with others in collaborative environments are critical for successful learning. Thus, it 
can be said that multidimensional learning facilitates principals' successful leadership development and that interacting with others provides sources for this learning.

Third, this study suggests that leadership development should be understood as an ongoing process that includes interactive relations between critical reflection and learning environments. Although my data showed consistent patterns, the findings highlight important differences in assumptions and strategies with regard to participants' leadership practices. These differences depend on learning environments, including influential relationships, access to resources, and the participants' school contexts. For example, Arlene was encouraged to realize her strengths as a leader by her husband who knew her personality. Her access to alternative perspectives helped her rethink her decisions as a leader. For Mary, having students from highly diverse backgrounds and implementing a Montessori curriculum drove her to utilize strategies to support individualized learning for students and teachers. Thus, the participants' leadership development and personal and/or professional environments interacted with each other, resulting in cyclical learning processes (Antonacopoulou and Bento, 2003; Mackay, 2012). In reflecting on the participants' stories, I found this iterative process reinforced their critical reflection and the development of leadership strategies. My analysis implies that experience should be conceptualized as an ongoing process (Zepeda et al., 2014), not as a fixed formation of prior experiences, to better understand leadership development (Mackay, 2012). In this ongoing process of learning, school leaders center themselves as learners and expand the scope of leadership development as they make changes.

I acknowledge several limitations of the study. First, although this study uncovered the mechanisms of transformative learning in principal leadership development, the findings do not link broader societal changes to these learning outcomes. Freire (2000) and Mezirow (2012) suggested transformative learning can result in social change by questioning dominant ideologies and power, but this study does not provide strong evidence of this happening. However, the questions I asked during the interview may explain the lack of attention participants gave to questioning power/ dominant structures. Additionally, literature on transformative learning theory is inconclusive about whether transformative learning leads to societal changes. 
Future research might explore the potential of transformative learning as a tool for promoting changes in broader social settings given recent literature on leadership that highlights social justice and equity issues as matters of importance. Second, in relation to the number of participants and methods, it is necessary to be careful in interpreting the findings. Because of the limited number of interviews and observations, the findings should be understood within the contexts of the individual participants. Future studies using ethnographic approaches or multiple interviews for each participant may uncover more details about principals' transformative learning mechanisms. Moreover, my research mainly focuses on the principals' own perspectives, with fieldnotes to record their interactions, and my conversations with other school members. Thus, I recommend future research that connects principals' perceptions on their own transformative learning with their leadership practices as recognized by teachers or students.

\section{Conclusion}

In conclusion, this study provides evidence with regard to how school principals experience transformative learning, which can lead to actual change in leadership practices. The findings of this study reveal how leaders reinterpret their own experiences and how these inform their leadership practices and perceptions. My analysis aligns with Drago-Severson's (2009) argument that authentic learning develops leaders' cognitive, emotional, and relational capacities. This, in turn, leads to actual change in their leadership practices. If learning is about change, then, for school principals, learning and leadership development are inseparable.

In this respect, the study contributes to knowledge about school principals' leadership development and its role in promoting authentic learning. First, using a transformative learning lens grounded in adult learning theories, this study bridges knowledge gaps between learning theories and principal leadership development. The theoretical framework of this study permitted me to explore the mechanisms of principals' authentic learning experiences and the influence such experiences have on leadership practices, an influence that is supported by theories of learning. Second, this study adds evidence of 
leadership learning beyond formal learning settings, something that has rarely been examined in existing literature. Although formal programs are only one of the elements that shape leadership performance (Leithwood and Levin, 2005), leadership development literature has focused predominantly on learning through programs. My findings fill this gap by examining leadership learning in broader settings. Third, this study provides implications for conceptualizing experience as a resource for leadership learning. By elaborating disorienting dilemmas that require critical reflections, the results suggest that challenging preexisting meaning structures is crucial with regard to making changes for leaders who are adult learners.

Being a leader requires placing learning at the center of leadership, especially given the complexity and uncertainty of current educational environments (Antonacopoulou and Bento, 2003; Mackay, 2012). This study helps us understand school leaders who enact authentic learning processes by developing themselves as skillful leaders.

Acknowledgments The author would like to thank Dr. Kristy Cooper Stein, Dr. John Yun and Dr. Susan Printy for their helpful comments on previous drafts. The author would also like to thank the participants of this study and the two anonymous reviewers.

Conflicting interests The author declared no potential conflicts of interest with respect to the research, authorship, and/or publication of this article.

Funding This research was supported by Doctoral Research Small Grant, from the College of Education at Michigan State University.

\section{References}

Antonacopoulou ER and Bento RE (2003) Methods of 'learning leadership':

Taught and experiential. In: Storey J (ed.) Leadership in Organizations: Current Issues and Key Trends. London: Routledge, pp. 81-103.

Auerbach C and Silverstein LB (2003) Qualitative Data: An Introduction to Coding and Analysis. New York: NYU Press.

Blumer H (1969) Symbolic Interactionism: Perspective and Method. Upper Saddle River, NJ: Prentice-Hall.

Borko H (2004) Professional development and teacher learning: Mapping the terrain. Educational Researcher 33(8): 3-15.

Bransford JD, Brown AL and Cocking RR (2000) How People Learn: Brain, Mind, 
Experience and School. Expanded edition. Washington, DC: The National Academies Press.

Brockett RG (1985) The relationship between self-directed learning readiness and life satisfaction among older adults. Adult Education Quarterly 35(4): 210-219.

Brown JS and Duguid P (1991) Organizational learning and communitiesof-practice: Toward a unified view of working, learning, and innovation. Organization Science 2(1): 40-57.

Bush T (2013) Leadership development for school principals: Specialised preparation or post-hoc repair? Educational Management Administration \& Leadership 41(3): 253-255.

Candy PC (1991) Self-Direction for Life-Long Learning. San Francisco, CA: Jossey-Bass.

Charaniya NK (2012) Cultural-spiritual perspective of transformative learning. In: Taylor EW and Cranton P (eds) The Handbook of Transformative Learning: Theory, Research, and Practice. San Francisco, CA: Jossey-Bass, pp. 231-244.

Cranston N (2013) School leaders leading: Professional responsibility not accountability as the key focus. Educational Management Administration \& Leadership 41(2): 129-142.

Cranton P and Taylor E (2012) Transformative learning theory: Seeking a more unified theory. In: Taylor EW and Cranton P (eds) The Handbook of Transformative Learning: Theory, Research, and Practice. San Francisco, CA: Jossey-Bass, pp.-20.

Creswell JW (2007) Qualitative Inquiry and Research Design: Choosing among Five Traditions. 2nd ed. Thousand Oaks, CA: SAGE Publications.

Creswell JW and Miller DL (2000) Determining validity in qualitative inquiry. Theory into Practice 39(3): 124-130.

Crow GM and Whiteman RS (2016) Effective preparation program features: A literature review. Journal of Research on Leadership Education 11(1): 120-148.

Danzig A, Wright W and Borman KM (2007) Using story and narrative to enhance the professional development of learner-centered leaders. In: Danzig A, Borman K, Jones B and Wright W (eds) Learner-Centered Leadership: Research, Policy, and Practice. Mahwah, NJ: Lawrence Erlbaum Associates, pp. 251-274.

Davis SH, Leon RJ and Fultz M(2013) How principals learn to lead: The comparative influence of on-the-job experiences, administrator credential programs, and the ISLLC standards in the development of leadership expertise among urban public school principals. International Journal of Educational Leadership Preparation 8(1): 1-24.

Dirkx JM (2001) The power of feelings: Emotion, imagination, and the construction of meaning in adult learning. New Directions for Adult and Continuing Education 2001(89): 63-72.

Dirkx JM (2008) The meaning and role of emotions in adult learning. New Directions for Adult and Continuing Education 2008(120): 7-18.

Dirkx JM (2012) Nurturing soul work: A Jungian approach to transformative learning. In: Taylor EW and Cranton P (eds) The Handbook of Transformative 
Learning: Theory, Research, and Practice. San Francisco, CA: Jossey-Bass, pp. 116-130.

Dix M(2016) The cognitive spectrum of transformative learning. Journal of Transformative Education 14(2): 139-162.

Donaldson Jr GA (2008) How leaders learn: Cultivating capacities for school improvement. New York, NY: Teachers College Press.

Drago-Severson E (2009) Leading Adult Learning: Supporting Adult Development in our Schools. Thousand Oaks, CA: Corwin Press.

Drago-Severson E and Blum-DeStefano J (2014) Leadership for transformational learning: A developmental approach to supporting leaders' thinking and practice. Journal of Research on Leadership Education 9(2): 113-141.

Emerson RM, Fretz RI and Shaw LL (2011) Writing Ethnographic Fieldnotes. Chicago, IL: University of Chicago Press.

Erickson F and Gutierrez K (2002) Comment: Culture, rigor, and science in educational research. Educational Researcher 31(8): 21-24.

Fishman B, Davis EA and Chan CKK (2014) A learning sciences perspective on teacher learning research. In: Sawyer RK (ed.) The Cambridge Handbook of the Learning Sciences. Cambridge: Cambridge University Press, pp. 707-725.

Freire P (2000) Pedagogy of the Oppressed. New York: Continuum.

Friend J, Adams A and Curry G (2011) Breaking news: Utilizing video simulations to improve educational leaders' public speaking skills. Journal of Research on Leadership Education 6(5): 234-249.

Fullan M (2009) Large-scale reform comes of age. Journal of Educational Change 10(2-3): 101-113.

Garrison DR (1997) Self-directed learning: Toward a comprehensive model. Adult Education Quarterly 48(1): 18-33.

Ginsberg MB, Knapp MS and Farrington CA (2014) Using transformative experiences to prepare instructional leaders through doctoral education. Journal of Research on Leadership Education 9(2): 168-194.

Glesne C (2006) Becoming Qualitative Researchers. Boston, MA: Pearson.

Greenhill J, Richards JN, Mahoney S, Campbell N and Walters L (2018) Transformative learning in medical education: Context matters, a South Australian longitudinal study. Journal of Transformative Education 16(1): 58-75.

Guglielmino PJ and Roberts DG (1992) A comparison of self-directed learning readiness in U.S. and Hong Kong samples and the implications for job performance. Human Resource Development Quarterly 3(3): 261-271.

Hargreaves A and Fullan M(2012) Professional Capital: Transforming Teaching in Every School. New York: Teachers College Press.

Immordino-Yang MH (2015) Emotions, Learning, and the Brain: Exploring the Educational Implications of Affective Neuroscience. New York: WW Norton \& Company.

Kegan R and Lahey LL (2009) Immunity to Change: How to Overcome it and 
Unlock Potential in Yourself and Your Organization. Boston, MA: Harvard Business Press.

Knowles MS (1975) Self-Directed Learning: A Guide for Learners and Teachers. Chicago, IL: Follett Publishing Company.

Knowles MS (1984) Andragogy in Action: Applying Modern Principles of Adult Learning. San Francisco, CA: Jossey-Bass.

Kolb DA (2015) Experiential Learning: Experience as the Source of Learning and Development. Upper Saddle River, NJ: Pearson Education.

Leithwood KA and Levin B (2005) Assessing School Leader and Leadership Programme Effects on Pupil Learning. Research Report No. 662. London: DfES Publications.

Leithwood KA, Louis KS, Anderson S and Wahlstrom K (2004) Review of Research: How Leadership Influences Student Learning. Minneapolis and St Paul, MN: University of Minnesota, Center for Applied Research and Educational Improvement. Available at: https://www.wallacefoundation.org/knowledgecenter/Documents/How-Leadership-Influences-Student-Learning.pdf (accessed 20 September 2018).

Lincoln YS and Guba EG (1985) Naturalistic Inquiry. Newbury Park, CA: SAGE Publications.

Long HB (1994) Resources Related to Overcoming Resistance to Self-Direction in Learning. San Francisco, CA: Jossey-Bass.

Louis KS and Lee M (2016) Teachers' capacity for organizational learning: The effects of school culture and context. School Effectiveness and School Improvement 27(4): 534-556.

Louis KS, Hord SM and von Frank V (eds) (2016) Reach the Highest Standard in Professional Learning: Leadership. Thousand Oaks, CA: Corwin Press.

Mackay F (2012) "I don't have to be like my principal”: Learning to lead in the post-compulsory sector. Educational Management Administration \& Leadership 40(3): 392-409.

Mann D, Reardon RM, Becker JD, Shakeshaft C and Bacon N (2011) Immersive, inter- active, web-enabled computer simulations as a trigger for learning: The next generation of problem-based learning in educational leadership. Journal of Research on Leadership Education 65(5): 272-287.

Maslow AH (1954) Motivation and Personality. New York: Harper and Row.

Matthews LJ and Crow GM (2010) The Principalship: New Roles in a Professional Learning Community. Boston, MA: Allyn \& Bacon.

Maxwell JA (2012) Qualitative Research Design: An Interactive Approach. Thousand Oaks, CA: SAGE Publications.

Merriam SB (ed.) (2007) Non-Western Perspectives on Learning and Knowing: Perspectives from around the World. Malabar, FL: Krieger.

Merriam SB and Bierema LL (2014) Adult Learning: Linking Theory and Practice. San Francisco, CA: Jossey-Bass.

Merriam SB, Caffarella RS and Baumgartner LM (2013) Learning in Adulthood: A 
Comprehensive Guide. 3rd ed [Kindle version]. San Francisco, CA: Jossey-Bass.

Mezirow J (1991) Transformative Dimensions of Adult Learning. San Francisco, CA: Jossey-Bass.

Mezirow J (2000) Learning as Transformation: Critical Perspectives on a Theory in Progress. San Francisco, CA: Jossey-Bass.

Mezirow J (2009) An overview on transformative learning. In: Illeris K (ed.) Contemporary Theories of Learning: Learning Theorists in Their Own Words. New York: Routledge, pp. 90-105.

Mezirow J (2012) Learning to think like an adult. In: Taylor EW and Cranton P (eds) The Handbook of Transformative Learning: Theory, Research, and Practice. San Francisco, CA: Jossey-Bass, pp. 73-95.

Nathan MJ and Sawyer RK (2014) Foundations of the learning sciences. In: Sawyer RK (ed.) The Cambridge Handbook of the Learning Sciences. Cambridge: Cambridge University Press, pp. 21-43.

Osterman K, Furman G and Sernak K (2014) Action research in EdD programs in educational leadership. Journal of Research on Leadership Education 9(1): 85-105.

Patton MQ (2002) Qualitative Research and Evaluation Methods. Thousand Oaks, CA: SAGE Publications.

Patton MQ (2015) Qualitative Research and Methods: Integrating Theory and Practice. Thousand Oaks, CA: SAGE Publications.

Peterson K (2002) The professional development of principals: Innovations and opportunities. Educational Administration Quarterly 38(2): 213-232.

Piaget J (1972) Intellectual evolution from adolescent to adulthood. Human Development 16: 346-370.

Roberts SM and Pruitt EZ (2009) Schools as Professional Learning Communities: Collaborative Activities and Strategies for Professional Development. 2nd ed. Thousand Oaks, CA: Corwin Press.

Robinson OC (2014) Sampling in interview-based qualitative research: A theoretical and practical guide. Qualitative Research in Psychology 11(1): 25-41.

Robinson OC and Smith JA (2010) Investigating the form and dynamics of crisis episodes in early adulthood: The application of a composite qualitative method. Qualitative Research in Psychology 7:170-191.

Rogers C (1983) Freedom to Learn for the 8os. Columbus, OH: Charles E. Merrill. Saldaña J (2015) The Coding Manual for Qualitative Researchers. Thousand Oaks, CA: SAGE Publications.

Sawyer RK (2014) The Cambridge Handbook of the Learning Sciences. Cambridge: Cambridge University Press.

Smagorinsky P (2008) The method section as conceptual epicenter in constructing social science research reports. Written Communication 25(3): 389-411.

Smylie MA, Bennett A, Konkol P and Fendt CR (2005) What do we know about developing school leaders? A look at existing research and next steps for 
new study. In: Firestone WA and Riehl C (eds) A New Agenda for Research in Educational Leadership. New York: Teachers College Press, pp. 138-155.

Stevens-Long J, Schapiro SA and McClintock C (2012) Passionate scholars: Transformative learning in doctoral education. Adult Education Quarterly 62(2): 180-198.

Stuckey HL, Taylor EW and Cranton P (2013) Developing a survey of transformative learning outcomes and processes based on theoretical principles. Journal of Transformative Education 11(4): 211-228.

Taylor EW and Cranton P (2013) A theory in progress? Issues in transformative learning theory. European Journal for Research on the Education and Learning of Adults 4(1): 35-47.

Taylor K (2006) Autonomy and self-directed learning: A developmental journey. In: Hoare C (ed.) Handbook of Adult Development and Learning. Oxford: Oxford University Press, pp. 196-218.

Vandenberghe R (2003) Beginning primary school principals in Belgium: How they deal with external influences and develop professionally. In: annual meeting of the American Educational Research Association, Chicago, USA, 21-25 April 2003.

Vigotsky LS (1978) Mind in Society: The Development of Higher Psychological Processes. Cambridge, MA: Harvard University Press.

Walker J (2017) Shame and transformation in the theory and practice of adult learning and education. Journal of Transformative Education 15(4): 357-374.

Wang VC and Cranton P (2013) Transformative learning and technological applications in adult and vocational education. International Journal of Information and Communication Technology Education 9(1): 26-37.

Young JR, Bullough Jr RV, Draper RJ, Smith LK and Erickson LB (2005) Novice teacher growth and personal models of mentoring: Choosing compassion over inquiry. Mentoring \& Tutoring: Partnership in Learning 13(2): 169-188.

Zepeda SJ (2015) Job-Embedded Professional Development. New York: Routledge.

Zepeda SJ, Parylo O and Bengtson E (2014) Analyzing principal professional development practices through the lens of adult learning theory. Professional Development in Education 40(2): 295-315.

Zambo D and Isai S (2013) Action research and the educational doctorate: New promises and visions. Journal of Research on Leadership Education 8: 97-112.

\section{About the author}

Taeyeon Kim was a PhD candidate in K-12 educational administration in the College of Education at Michigan State University. Her research interests include leadership development and learning, the intersection of accountability policies and leadership, philosophical inquiry about leadership, and the links between education and social change. 


\section{Appendix A}

\section{Interview questions}

1. After your teaching and administrative experiences, what made you decide to work as a school principal?

2. Can you share any experiences that make you happy or feel bad about your work as a principal?

3. Can you tell me what the most difficult challenge of being a principal is? I would like to talk about your transformative learning experiences. Transformative learning can be understood as learning that makes people experience qualitative shifts in their ways of assuming, analyzing, understanding, and interpreting their experiences and contexts. (provide my personal examples to explain transformative learning). Based on this, have you ever experienced transformative learning related to your leadership as a principal? If so, can you tell me your story? (If not, why do you think so?)

4. What did you learn from that experience? How did those experiences change your life, personally and professionally?

5. Do you think that learning experience changed your ways of thinking about leadership and your practices as a leader? If so, how did that experience change your perceptions and practices as a leader?

6. What kinds of factors do you think influenced or led your transformative learning?

7. Specific questions related to observations were followed for the two focal participants. 